\title{
House Prices, Household Leverage, and Entrepreneurship*
}

\author{
Stefano Corradin \\ Alexander Popov \\ European Central Bank \\ European Central Bank
}

First version: February 15, 2012

This version: February 14, 2013

\begin{abstract}
This paper estimates the causal effect of changes in home equity and household leverage on entrepreneurship and business ownership. Using a large individual-level survey dataset, we show that higher home equity increases the probability of transition into entrepreneurship, while higher household leverage has a significantly positive effect on business equity ownership. These effects are stronger in "hot" housing markets where agents expect house prices to keep increasing in the future. Our results persist when we use the topological elasticity of housing supply to generate variation in home equity that is orthogonal to entrepreneurial choice.
\end{abstract}

JEL classification: G21, L26

Keywords: Home equity, business equity, entrepreneurship

${ }^{*}$ We thank Patrick Bolton, Luigi Guiso, Harry Huizinga, Ross Levine, Deborah Lucas, Alexander Michaelides, Dwight Jaffee, Jonathan Parker, Ken Singleton, Phil Strahan, Amir Sufi, and seminar participants at the ECB, the Third Entrepreneurial Finance and Innovation Conference in Boston and the ASSA/AREUEA 2013 for valuable comments. The opinions expressed herein are those of the author and do not necessarily reflect those of the ECB or the Eurosystem. 


\section{Introduction}

The U.S. housing boom of the 2000s and the subsequent deep recession revived the interest of both academics and policy makers in the real economic consequences of home ownership. One theme that has so far been left neglected is the link between housing and entrepreneurship. In this paper, we present the first systematic attempt to incorporate the dynamics of homeownership and of house prices in a model of entrepreneurial choice. We then test the implications of the model using household level data on property values, housing leverage, and labor choices. As an illustration of our results, Figure 1 plots the change in establishments births between 2003 and 2006 (the peak of the housing boom) against the change in the state-level Federal Housing Finance Agency house price indexes over the same period, inflation adjusted, for the 50 U.S. states plus the District of Columbia. A positive relationship is readily available, suggesting higher entrepreneurial activity in states with a house price boom.

\section{Insert Figure 1 here}

In theory, home ownership can affect entrepreneurship through several channels. The first is related to liquidity constraints. A number of influential papers have argued that would-be entrepreneurs may be discouraged from switching into entrepreneurship if low levels of own wealth and/or borrowing constraints prevent them from raising sufficient capital (as in Evans and Jovanovic (1989), Evans and Leighton (1989), Holtz-Eakin, Joulfain, and Rosen (1994), Blanchflower and Oswald (1998) and Paulson and Townsend (2004)). Increasing home equity may alleviate such liquidity constraints by enabling would-be entrepreneurs to borrow against the value of their property. Alternatively, declining home equity can effectively raise households' borrowing constraints and depress entrepreneurship. These are important consideration given that one's home is the main asset for most Americans and that residential property represent $60 \%$ of all personal wealth in the U.S. (U.S. Census 2010). Hurst and Stafford (2004) highlight the use of home equity as a 
mechanism by which households smooth their consumption over time. When faced with a negative income shock, a household can sustain their consumption by tapping into their home equity when more liquid assets are not available. Mian and Sufi (2010) empirically investigate how existing homeowners responded to the rising value of their home equity from 2002 to 2006, a channel they refer to as the home equity-based borrowing channel. They provide evidence that the home equitybased borrowing channel, which may have been fueled by easy availability of mortgage credit, was an important cause of the rapid rise in household leverage before the down turn. Their findings lend support to the view that home equity-based channel was used for real outlays but they cannot empirically identify the final use.

The second channel is related to entrepreneurship being a superior good. Hamilton (2000) shows that most entrepreneurs enter and persist in business although they have both lower initial earnings and lower income growth than paid employees, and argues that there are important non-pecuniary benefits of entrepreneurship. Hurst and Lusardi (2004) argue that personal wealth is important only for the richest households, and that once these are excluded from the sample, there is no statistical relationship between wealth and entrepreneurial choices. The authors thus challenge the established view that liquidity constraints matter a lot for entrepreneurship. Instead, they argue that entrepreneurship may contain a "luxury good" component. Namely, as households become wealthier, they are more likely to purchase the benefits associated with owning a business, like prestige, power over decision-making, a flexible time schedule, etc. If this is the case, then more households will be more likely to switch to self-employment during housing booms when personal wealth is increasing.

We use both OLS and an Instrumental Variables analysis of the effect of home equity on the transition to entrepreneurship. We motivate our empirical analysis with a simple but novel model of career choice. The novelty is the collateral channel of homeownership. In our model, agents start out as fixed-wage workers and can choose to become entrepreneurs in each following period. 
Their value function in each period depends on own wealth (as in Quadrini (2000), Caggetti and De Nardi (2006) and Bruera (2009)), but also on housing prices through three channels. The first one is that the current level of housing prices affects the equity value they can extract from their home. The housing stock has a collateral value component, beyond the value derived from the direct consumption of housing services, due to prospects of limits on the amount of borrowing. The second channel is predictability in housing returns. We follow Corradin, Fillat, and Vergara (2012) assuming that the housing market can be in a "hot" regime (when house prices are expected to keep increasing) or in a "cold" regime (when house prices are expected to stay flat). The last channel results from the interaction between the first two channels and the cost of external financing available to the potential entrepreneur. As in Quadrini (2000), the entrepreneur can borrow up to an amount that corresponds to the difference between the maximum permitted level of capital investment and total net wealth. But external debt is costly and the cost depends on the cost of intermediation that lenders charge and the ratio of debt to capital. As a result, leverage depends on the proportional cost charged by lenders, the home equity and the current housing return regime.

The key implications of the model are twofold. First, for high enough values of home equity, agents switch into entrepreneurship with less equity in a period of high house price appreciation because expected future rises in the housing prices increase the equity they can extract from their home allowing them to finance the capital investment necessary to start a business. Second, once they become entrepreneurs, they extract the full amount of equity from their home in order to finance their business. The model thus predicts a positive correlation between current home equity and future transition into entrepreneurship, and a negative correlation between current home equity and current business equity.

We test our model using microdata on housing and business ownership from the Survey of Income and Program Participation (SIPP) of the U.S. Census Bureau from 1997 to 2006. In every survey year, the respondents are asked about whether they run and/or operate a business, about 
the value of their business equity, and about the value of their house and the size of the mortgage (if any). The survey also contains household-level data on a variety of relevant household characteristics, like the household's liquid wealth and labor income and the head's age, race, education, and marital status. We use information on 44,141 unique households that were interviewed during the years 1996 - 2000, $2001-2003$, and $2004-2006$, for a total of 108, 970 observations. We also use proxies for house price boom-bust periods from state-level data on housing prices developed in Corradin, Fillat, and Vergara (2012).

We confirm the findings in previous studies that the probability of becoming an entrepreneur increases in education and is higher for agents who are white and married, as well as in local markets characterized by higher unemployment. Importantly, we find that the probability of switching into entrepreneurship is strongly positively correlated with the value of the home equity. A doubling of home equity increases the probability that a non-business owning household will become entrepreneurs in the future by up to $2.4 \%$. The results are statistically significant regardless of whether we define business ownership in terms of owning and operating a business, in terms of holding non-zero business equity, or in terms of either. This effect is robust to controlling for a wide range of demographic and income characteristics, for the local business cycle, and for the bankruptcy code. It also exists independently of a "luxury good" component of housing whereby individuals whose house is appreciating in value can be more likely to purchase the non-pecuniary benefits associated with running a business. We also confirm the prediction of our model that these effects are stronger during housing booms. The intuition is that when agents expect the value of their property to increase in the future, they can switch to entrepreneurship at lower current levels of home equity. Finally, we find a strong negative correlation between home equity and business equity for business owners, implying that once they switch away from fixed income, entrepreneurs do tend to draw down their home equity in order to finance their business investment. In this regard, our findings are similar to Chaney, Sraer and Thesmar (2011) who provide evidence that 
when the value of a firm's real estate appreciates by $1 \$$, its investment increases approximately by \$0.06 examining US listed firms over the 1993-2007 period. Then, in order to distinguish the effect of housing through the collateral channel from its effect through the wealth channel, we control for property values. While we find evidence of this "luxury" component of entrepreneurship, our main results remain unchanged.

In our tests we also account for the fact that both entrepreneurial activity and homeownership may be driven by an unobservable component, like the household's degree of risk aversion. We employ the strategy suggested by Chetty and Szeidl (2012), namely, using the average price in the state in the current year and in the year when the house was bought, in interaction with the statelevel topological elasticity of housing supply from Saiz (2010), to extract the endogenous element of home equity. The idea behind these instruments is that higher house prices in the past imply higher mortgage in the past and so lower equity today, while higher prices today imply higher equity for houses with identical purchase prices because of price appreciation, and these effects are more likely to translate into higher housing prices in states with less elastic housing supply. Our results remain robust to this alternative empirical approach.

Our reduced form estimates imply potentially important linkages between housing and real economic activity. For example, our results imply that the housing boom before the Great Recession may have resulted in higher rates of new business creation, while increasing levels of mortgage debt since 2006 may have depressed self-employment, denting the positive effect on new business creation of higher unemployment rates. Because such analysis ignores the effect of housing market shocks on asset prices, quantifying the effect of housing on entrepreneurship would require a general equilibrium model of financial, real estate, and asset markets. Our estimates should serve to inform such an analysis.

The paper proceeds as follows. Section 2 develops the career choice model with homeownership and stochastic house prices. Section 3 presents a calibration exercise. Section 4 develops the 
empirical strategy. Section 5 presents the data. Section 6 reports the empirical estimates. Section 7 concludes.

\section{The Model}

Consider an agent with wealth $a$. The agent lives for $T$ periods and in each period $t$ she chooses numeraire consumption $c_{t}$ and the amount of one period risk free financial assets to bring the next period, $\tilde{a}_{t+1}$. Let $h$ denote the size of the housing stock that provides a constant flow of housing services to the agent. We make the assumption that (i) the housing stock does not depreciate; (ii) the flow of housing services is $g(h)=g \times h$, where $g>0$. The housing size in the first period is given and the agent does not change the house regardless of the path of her income, housing price and wealth. Thus, we ignore the possibility that the agent can adjust the level of housing services and move to a larger or smaller house. The agent's utility from housing consumption and numeraire consumption is given by

$$
u(c, g(h))=\frac{\left(c^{\beta} g(h)^{1-\beta}\right)^{1-\gamma}}{1-\gamma}
$$

Let $p_{t}$ denote the relative price of one unit of housing, in terms of the numeraire nondurable consumption good. We assume that house price follows a binomial process with time-varying parameters $u_{i}$ ("up") and $d_{i}$ ("down") and probability $\pi_{i}$. The initial house price value is $p_{0}$ and the tree as $N$ steps. In the continuous-time model, over a discrete time period $\Delta t=T / N$, we have

$$
\Delta \log p=\left(\mu_{i}-\sigma^{2} / 2\right) \Delta t+\sigma_{p} \Delta W,
$$

where $\mu_{i}$ is the expected house price growth rate, $\sigma$ determines the standard deviation of the growth 
process and $W$ is a Brownian motion. We approximate this process assuming that

$$
u_{i}=e^{\left(\sqrt{\sigma^{2} \Delta t+\left(\mu_{i}-\sigma^{2} / 2\right)^{2} \Delta t^{2}}\right)}, \quad d_{i}=1 / u_{i} \quad \text { and } \quad \pi_{i}=0.5+\frac{\left(\mu_{i}-\sigma^{2}\right) \Delta t}{2 \log \left(u_{i}\right)}
$$

We follow Corradin, Fillat and Vergara (2012) in assuming that the house price mean growth rate, $\mu_{i}$, depends on some $n$-regime process, where the expected value is modeled through a Markov chain tracking the particular regime at a given point in time. For example, in the case of two regimes, the expected growth in house prices, $\mu_{i}$ can only take two values: $\mu_{i}=\mu_{h}$, where $h$ denotes the high growth regime, and $\mu_{i}=\mu_{l}$, where $l$ denotes the low growth regime, and $\mu_{h}>\mu_{l}$. The transition probability matrix of the Markov chain is denoted by $\Lambda$. The diagonals of this matrix represent the unconditional probabilities of staying in the current regime while the off-diagonal terms represent the probability of a regime shift, either form high to low, $\lambda_{h l}$, or from low to high, $\lambda_{l h}$. Then, the probability of moving from the regime $j$ to $i$ within time $\Delta t$ is approximately $\lambda_{j k} \Delta t$. We assume that the agent knows with certainty the regime of the economy, hence $\mu_{i}$ is observable by the agent at time $t$.

The agent can choose to be an entrepreneur or to work for a fixed wage $l$. In the first case, the agent's wealth at time $t$ is $a_{t}=b_{t}+h \times p_{t}$, where $b_{t}$ is the risk free asset and represents the financial wealth $\tilde{a}_{t}$. Interestingly, $a_{t}$ also corresponds to the home equity the agent holds when $b_{t}<0$. Then, we follow prior research by Kiyotaki and Moore (1997) in which a financing constraint is introduced

$$
b_{t} \geq-\phi \frac{h \times E\left[p_{t+1}\right]}{1+r_{D}}
$$

where $r_{D}$ is the interest rate. Prospects of limits to how much the agent can borrow introduce a collateral value to the housing stock. Increases in the value of a house enlarges the amount of permissible debt, and this adds to the value to home owning beyond the direct consumption of housing services. To ensure that that borrowing is risk-free, we impose a loan-to-value ratio and 
require that the agent is able to borrow up to $\phi$ fraction of the collateral value.

In the second case, she can generate output $\nu k^{\alpha}$, where $k$ is the input of capital and $\nu$ is the stochastic entrepreneurial ability of the agent, relative to her ability to earn a wage income. The optimal input of capital is determined by maximizing the profit net of the opportunity cost of capital that is $\Pi=\nu k^{\alpha}-\left(r_{t}+\delta\right) \kappa$, where $r_{t}$ will be defined later and $\delta$ is the depreciation rate of capital. We assume that $\nu$ follows a 2-regime Markov chain, where $\bar{\nu}>\underline{\nu}$, and the transition probability matrix is denoted by $\Theta$. The entrepreneur's wealth at time $t$ is $a_{t}=b_{t}+k_{t}+h \times p_{t}$, where $\tilde{a}_{t}=b_{t}+k_{t}$ represents the financial wealth.

For an agent with a sufficiently high $\nu, E[\Pi]>l$ so that she would generate higher income by choosing to become entrepreneur. As long there are no financial frictions, the model predicts that an agent with $E[\Pi]$ above a certain threshold becomes entrepreneur, otherwise she chooses to be a worker. With financial constraints, however, wealth $a$ and in particular housing $h \times p_{t}$ also become important. We assume that the agent can use the house as collateral. As in Quadrini (2000), we introduce the variable $r_{t}$ that is the cost of capital from internal and external source of finance. If $k_{t} \leq a_{t}$, the project is entirely financed with internally sources, $b_{t}+h \times p_{t}$, and the cost of capital is given by the opportunity $\operatorname{cost} r_{D}$. If $k_{t}>a_{t}$, part of the capital that is invested in the business is financed with costly debt, and the cost of capital is an increasing function of the ratio of debt to capital:

$$
r_{t}=r_{D}+\epsilon\left(\frac{k_{t}-a_{t}}{k_{t}}\right) \text { if } k_{t}>a_{t}
$$

where $\epsilon$ is a proportional cost per each unit of funds intermediated charged by a competitive lending market. The agent can borrow only up to a maximum amount, the size of which depends on the lending policy. This policy consists of lending up to the amount that the borrower will be able to repay with certainty at the end of the following period. If the entrepreneur invests $k$ units of capital in the business, then the minimum amount of resources that can be disposed of at the end of the period, and before repaying the debt, is given by $D R_{\min }=\underline{\nu} k^{\alpha}-\delta \kappa$, where $D R_{\min }$ stands 
for disposable resources when the shock takes the minimum possible value. The amount of funds that the entrepreneur has to pay back to the bank is given by $\left(k_{t}-a_{t}\right)\left(1+r_{t}\right)$ and this has to be smaller than $D R_{\min }$. Therefore, bankruptcy is not allowed.

Our model suggests a linkage between the capital input and the value of stock housing. In the next section, we will present some figures that motivate our empirical analysis and suggest that housing value $h \times p_{t}$ affects (i) the occupational choice, because the agent chooses to become entrepreneur, only if the agent has a net worth or home equity bigger than $a^{*}$; and (ii), after becoming an entrepreneur, the input of capital and therefore the income generated by the entrepreneur himself depends on increases in the values of the house.

At the beginning of each period, before any economic decisions are made, the current ability level $\nu$ is known with certainty, whereas next period's levels are uncertain. The agent chooses whether to be an entrepreneur or a fixed-wage worker during the current period. The agent's value function is

$$
V(\tilde{a}, p, i, j, t)=\max \left(V_{e}(\tilde{a}, p, i, j, t), V_{w}(\tilde{a}, p, i, t)\right)
$$

where $V_{e}(a, p, i, j, t)$ is the value function of the agent who manages an entrepreneurial activity during the the current period. The value function depends on the current level of financial wealth $\tilde{a}_{t}$, the current level of housing prices $p_{t}$, the current regime of house price appreciation $i$ and the current ability level $j$. We have

$$
V_{e}(\tilde{a}, p, i, j, t)=\max _{c_{t}, k_{t}} E_{0}\left[\sum_{t=1}^{T} \rho^{t-1} u\left(c_{t}, g(h)\right)+\rho^{T} \frac{a_{T}^{1-\gamma}}{1-\gamma}\right],
$$

where $\rho$ is the standard time discount factor and expectations $E_{0}$ are taken with respect to the stochastic processes driving house prices and the entrepreneur's profits. The evolution of the financial wealth is

$$
\tilde{a}_{t+1}=\left(1+r_{t}\right)\left(\tilde{a}_{t}-k_{t}\right)+(1-\delta) k_{t}-c_{t}+\nu k_{t}^{\alpha},
$$


subject to the following constraints:

$$
a_{t} \geq 0, \quad k_{t} \geq 0 \quad \text { and } \quad k_{t} \leq \tilde{a}_{t}+\phi \frac{h \times E\left[p_{t+1}\right]}{1+r_{D}}+\frac{D R_{\min }}{1+r_{t}}
$$

The function $V_{w}(\tilde{a}, p, i, j, t)$ is the value function of the agent who chooses to be a worker during the current period. We have

$$
V_{w}(\tilde{a}, p, i, t)=\max _{c_{t}} E_{0}\left[\sum_{t=1}^{T} \rho^{t-1} u\left(c_{t}, g(h)\right)+\rho^{T} \frac{a_{T}^{1-\gamma}}{1-\gamma}\right],
$$

subject to $a_{t} \geq 0$ and $b_{t} \geq-\phi\left(h \times E\left[p_{t+1}\right]\right) /\left(1+r_{D}\right)$, and the evolution of the financial wealth is

$$
\tilde{a}_{t+1}=\left(1+r_{D}\right) \tilde{a}_{t}+l-c_{t} .
$$

We make the following assumption on the occupational choice. In the first period, the agent is a fixed-wage worker and she can choose to become an entrepreneur in any following period. Later, the agent, as an entrepreneur, has the option to liquidate the capital at any time and to become again a fixed-wage worker.

\section{Numerical Simulations}

It is not possible to find properties of our model in closed-form, therefore a backward numerical procedure is developed and implemented in the context of a simple numerical example. Table 1 reports the model parameters. In order to parameterize the model we assume that each period corresponds to one year. We set the initial age at to 30 and the terminal age to 50 . Thus $T$ is 20 years. We assume a curvature of the utility function of 2 and a rate of time preference of $3 \%$. The parameter $1-\beta$ measures how much the agent values housing consumption relative to the numeraire consumption. It is set at 0.4 which is consistent with the average proportion of household housing 
expenditures in the US. Then, we assume a housing service flow, $g$, of $7.5 \%$, which is close to the estimates of housing user costs in the literature.

\section{Insert Table 1 here}

The risk free rate $r_{D}$ is set at $3 \%$, while the funding cost $\epsilon$ is set at $1 \%$. We follow Corradin, Fillat and Vergara (2012) in setting the house price mean growth rate process. They use the long Case-Shiller HPI time series dating back to 1925 to estimate the parameters of a 2-regime Markov switching process. They find that a model specification that allows the expected growth of house prices to switch only between two regimes captures sufficiently well the essential dynamics of U.S. house prices. They estimate a yearly growth rate of house prices of $-0.49 \%$ during the low growth regimes and a growth rate of $9.25 \%$ during the high regimes. Their analysis suggests that house prices are most often in a regime of low growth and the probability of being in a high regime is rather low, except in periods of large price appreciation, indicating that high growth regimes in the U.S. tend to occur relatively infrequently. This fact is also reflected in the estimated, time-invariant, transition probabilities of switching to the alternative regime in the next period: the probability of moving from a low to a high growth rate regime, $\lambda_{l h}$, is only about $3.43 \%$ (i.e., $1-0.9658=0.0343$ ), while the probability of moving from a high to a low growth rate, $\lambda_{h l}$, is $24.14 \%$. We assume a house price standard deviation of $10 \%$. We consider a fixed housing stock of 100 square feet and we normalize the housing price in the first period, $p_{0}$, at 1 . Then, our baseline scenario assumes a loan-to-value ratio, $\phi$, of $90 \%$.

In order to paramaterize the stochastic process of the entrepreneurial ability we assume that $\bar{\nu}=0.9$ and $\underline{\nu}=0.1$, while the probability of switching from low to high skill, $\theta_{l h}$, is $40 \%$ and the probability of switching from high to low skill, $\theta_{h l}$, is $30 \%$. In addition, we set the fixed-wage $l$ at 15 such that $E[\Pi]>l$ for certain levels of input of capital $k$. Capital depreciates at a rate $\delta$ of $9 \%$. We set the capital share $\alpha$ at 0.8 . 
The occupational choice is made by comparing the indirect utility of being a fixed wage worker, $V_{w}$, and the indirect utility of being an entrepreneur, $V_{e}$. Only if the agent has a home equity bigger than $a^{*}$, she chooses to become an entrepreneur. Figure 2 plots the investment in the entrepreneurial activity $k$ (solid red line) with respect to the liquid and housing wealth $b_{t}+h \times p_{t}$, in a period of low house price appreciation. The capital investment thus depends on the collateral value as well. The capital investment is positive, increasing and concave in $b_{t}+h \times p_{t}$, meaning that investment increases with housing value. When she starts the business, the capital investment growth rate is substantially higher than the wealth growth rate. Then, at some level of liquid and housing wealth, the precise value depends on the problem's parameters, it is optimal for the agent to invest at a lower but still positive rate. When the capital investment is above the 45 degree line, the agent is also using external financing paying the additional premium $\epsilon\left(k_{t}-a_{t}\right) / k_{t}$. In Figure 2 , we plot also the investment in the entrepreneurial activity $k$ (dashed green line) with respect to $b_{t}+h \times h_{t}$, in a period of high house price appreciation. Ceteris paribus, the capital investment is higher in high house price appreciation regime due to the increase of leverage. We provide the capital investment policy at two different times, $T-10$ (upper panel) and $T-2$ (lower panel). Intuitively, the entrepreneur invests less when she is approaching the terminal date $T$.

\section{Insert Figure 2 here}

Therefore, we have the testable implication that home equity increases the probability of becoming an entrepreneur. In addition, the house price dynamics is also affecting such decision making the home equity trigger time-varying. The model is suggesting that on average an individual with high entrepreneurial skill becomes an entrepreneur holding less home equity in a period of high house appreciation $a_{h}^{*}<a_{l}^{*}$. Although the agent is facing limits on the amount of borrowing, the collateral value of the housing stock is more valuable in periods of high house appreciation and therefore the agent can anticipate her decision exercising her option of becoming an entrepreneur. Then, house price dynamics affect the capital investment as well. The model predicts that on 
average entrepreneurs should invest more in period of high house price appreciation holding less home equity and should increase leverage relying more on external financing.

\section{Empirical Strategy}

There are two key implications of the theoretical model in the previous section. The first one concerns the transition from fixed-wage income to entrepreneurship. The model predicts that holding all else equal, an increase in house prices will increase the probability that an individual will transition into entrepreneurship. The intuition for this result is that if household leverage remains the same, a higher value of the property will increase the home equity, reducing the effective cost to the agent of switching from fixed income to variable income. The second implication is that holding all else equal, individuals transitioning into entrepreneurship will increase household leverage in order to increase their holding of business equity.

The first implication is tested using the following model:

$\operatorname{Prob}\left(\right.$ future business ownership $\left.{ }_{i j t}=1\right)=\alpha+\beta \cdot$ home equity $_{i j t}+\gamma \cdot X_{i j t}+\delta \Phi_{j t}+\varepsilon_{i j t}$,

where $X_{i j t}$ denotes a vector of demographic characteristics, such as race, gender, marital status, and education, for each household $i$ in state $j$ at time $t$. It also includes variables related to income and liquidity constraints. In particular, it includes the household's current labor income and its liquid wealth. Not accounting for wealth may bias our estimates upward because wealthier individuals may be simultaneously more likely to become entrepreneurs and to own a more expensive house. Theory predicts that the inability to acquire the capital necessary to start a business is one of the main theoretical obstacles faced by would-be entrepreneurs. A large literature has documented a positive relationship between initial wealth and subsequent business entry (Evans and Jovanovic, 1989; Evans and Leighton, 1989; Fairlie, 1999; Quadrini, 1999). However, more recent studies 
using detailed survey data have shown that such a positive relationship exists only at the top of the wealth distribution (Hurst and Lusardi, 2004). We take these considerations into account by including an up to fifth degree polynomial of household liquid wealth. $\Phi_{j t}$ is a matrix of state and year fixed effects and it controls for unobservable factors that are common for all individuals in a state and for all individuals during the same phase of the business cycle.

In addition to home equity, we also control for the property value directly. By doing so, we want to distinguish between the effect of owning a higher value property the "collateral channel" (households are more likely to become entreprneurs if they can extract home equity) and its effect through the "luxury good channel" (households are more likely to become entrepreneurs when they feel richer), as in Hurst and Lusardi (2004).

We test the second implication of the model by estimating the following model:

business equity $_{i j t}=\alpha+\beta_{1} \cdot$ home equity $_{i j t}+\beta_{2} \cdot$ house value $_{i j t}+\gamma \cdot X_{i j t}+\delta \Phi_{j t}+\varepsilon_{i j t}$,

where the independent variable is the amount of business equity, in USD, that each household $i$ in state $j$ declares in each period $t$. The only additional variable on the right-hand side relative to (12) is the value of the household's property. This allows us to distinguish the direct effect of higher household leverage on business equity ownership from the effect housing has on portfolio allocation through exposure to risk (Flavin and Yamashita (2002)), through an amplification of risk aversion (Grossman and Laroque (1990); Chetty and Szeidl, (2007)), or through the "luxury good" component of entrepreneurship . Consistent with the implications of the model, we expect that $\beta>0$ and $\beta_{2}<0$. Consistent with the idea of entrepreneurship being a superior good, we expect that $\beta_{1}>0$.

The main empirical challenge in identifying the underlying effects relates to left-out variable bias. For example, home equity may be negatively correlated with a component of labor income that is observable to the household but not to the econometrician. If this is the case, then individuals 
with low home equity may be less likely to transition into entrepreneurship not because they can extract less equity from their house to invest in their business, but because their lifetime fixed income is higher than what the econometrician observes. This will bias the estimate of $\beta$ upwards. Similarly, if households have heterogeneous risk aversion and less risk averse households buy larger houses, we would observe a spurious positive correlation between property values and business equity holdings.

To address these issues, we borrow the approach introduced in Chetty and Szeidl (2010) and exploit two instruments to generate variation in home equity and property value. Namely, we interact the average price of houses in the household's state in the current year and the average price of houses in the household's state in the year in which it bought the house with the state-level topological elasticity of housing supply from Saiz (2010). The intuition for this approach is the following. Consider two identical houses which were bought during the same year, but we observe the two households during different periods in time. The two households have the same mortgage (if they had the same initial assets) because the purchase price was the same, but the household observed during a housing boom will have higher home equity. Now consider two houses which have an identical price today, but one was bought in the past when home prices were high and the second was bought in the past when home prices were low. The household which owns the first house is likely to have lower equity (as it enjoyed less home price appreciation) and a higher mortgage (as it needed to borrow more). In addition to that, changes in the demand for housing is more likely to translate into higher home prices, rather than higher supply of new homes, in states where for topological and regulatory reasons housing supply is less elastic.

\section{Data}

We evaluate the implications of our model using household level survey data from the Survey of Income and Program Participation (SIPP) of the U.S. Census Bureau from 1997 to 2006. In 
each survey year, the respondents are asked questions related to business ownership. The survey also contains questions on the value of the house and on the size of the mortgage (if any), which allows us to distinguish the collateral effect of higher household leverage from the wealth effect of higher property values. We also construct proxies for house price boom-bust periods at the state level. These data allow us to evaluate the main predictions of our model relating house prices and household leverage to transition into business ownership and ownership of business equity.

The survey contains household-level data on a variety of individual characteristics. In particular, it has a detailed inventory of the household's financials, in addition to demographic characteristics which are theoretically related to entrepreneurial choice and business equity ownership, like age, education, and marital status. At each moment, SIPP tracks approximately 30, 000 households. During the period considered, information was collected from three consecutive groups of households that were interviewed during the years 1996 - 2000 (four times), 2001 - 2003 (three times), and $2004-2006$ (two times), respectively. The three SIPP panels put together contain information on 44, 141 unique households, for a total of 108, 970 observations.

During its active period, each panel is interviewed every year, while panels of households do not overlap across periods. SIPP over-samples from areas with high poverty concentrations, which should be taken into account when interpreting the results. Its longitudinal features enable the analysis of dynamic characteristics, such as changes in employment and income, changes in household and family composition, or housing dynamics. The survey's cross-sectional features allow us to keep track of household wealth. It also allow us to study the empirical implications of the model outlined above. In particular, we focus on the identification that arises when the value of the property and of the home equity changes.

Theory provides little guidance on how to classify "entrepreneurs" (Hurst and Lusardi (2004)). The SIPP allows us to distinguish between direct ownership of business and ownership of business equity, which may or may not be ownership of equity in the household's own business. Specifically, 
we utilize responses in the survey to the question "Did the household own and operate a business in the previous year?" to define business ownership, and responses to the question "What is the value in dollars of the household's total business equity?" to define ownership of business equity. This strategy is somewhat richer that previous studies utilizing household data on entrepreneurship. For example, Hurst and Lusardi (2004) define entrepreneurship from a question in the Panel Study of Income Dynamics (PSID) which asks household whether they "[...] own a business [...] or have a financial interest in any business enterprise", so they are unable to distinguish between direct and indirect ownership. The main results of the paper remain unaffected when in robustness exercises we employ alternative definitions of entrepreneurship.

In terms of the household's financials, we calculate liquid wealth as total wealth minus total debt. Total debt includes any mortgage on the household's current home. Total wealth excludes the value of equity in the house (which is not liquid).

To examine the role of property values and household leverage on the transition into entrepreneurship, we create a pooled sample of non-business owners from the three survey waves. A household is defined to enter entrepreneurship if either the household head or the spouse owns and operates a business in (i) any of the subsequent periods of the same survey wave, or (ii) in the very next period of the same survey wave. Consistent with Hurst and Lusardi (2004), we eliminate households in which the head is still in school or is close to retirement and focus on non-retired household heads between the ages of 22 and 60 . There are 40,024 households who were observed more than once, for whom all relevant information is available, and who started out as non-business owners. 678 of those households subsequently became business owners.

Table 2 reports descriptive statistics about the subsample of household that transitioned into entrepreneurship during the following year(s). We compare those to descriptive statistics about the subsample of household that remained non-business owners. On average, those transitioning into entrepreneurship have acquired more education and are more likely to be white, male, and married, 
as well as to have higher labor income and higher liquid wealth. Importantly, those transitioning into entrepreneurship own a more expensive house, and this higher property value is reflected in both a higher mortgage and in higher household equity.

\section{Insert Table 2 here}

In addition to household information, we include data on GSP growth, state unemployment, and homestead exemptions. The economic rationale for including the first two is clear: A more vibrant economy and a more depressed local labor market can raise the returns to self-employment (see Fairlie, 2010). Regarding the latter, the homestead exemption enables a filer for bankruptcy to retain home equity in his primary residence up to the exemption amount. Because the debts of the firm are personal liabilities of the firm's owner, lending to the firm is legally equivalent to lending to its owner. Berkowitz and White (2004) show that as a result of that, small firms located in states with unlimited homestead exemptions are more likely to be denied credit. The homestead exemption ranges from $\$ 0$ in Maryland to an unlimited amount in 8 US states in 2006. As such, a higher exemption may increase the probability of transitioning into self-employment by imposing a lower cost on a potential business exit.

\section{Empirical Analysis}

\subsection{Baseline result}

We begin by estimating Equation (12) using OLS. In the benchmark specification, we use ownership and operation of a business firm as the main definition of entrepreneurship. Column (1) of Table 3 reports the regression estimates of the probability of owning and operating a business in the future on home equity and the full range of variables capturing the household's demographic characteristics and financial situation. The regressions results are from a sample of 39,999 households who were non-business owners at the time of their first interview in each survey wave. 


\section{Insert Table 3 here}

The estimates imply that households whose head has higher average education, is white, and is married, are more likely to transition into entrepreneurship in the future, while the spline of liquid wealth has no effect on future business ownership. These results are fully consistent with Hurst and Lusardi (2004). In addition, individuals are more likely to become entrepreneurs in states with higher unemployment. This result is consistent with Fairlie (2010) who uses data from the Current Population Survey over 1996 - 2009 and finds a positive association between local unemployment rates and the probability that an individual starts a business. Finally, as expected, a higher homestead exemption increases the probability of switching from a fixed income to business ownership in the future.

Turning to our variable of interest, we find that holding demographic characteristics, liquid wealth, disposable income, and the business cycle constant, individuals are more likely to make the transition to business ownership in the future if they have higher home equity in their house. In terms of our model, this is because when housing prices increase and raise the value of the property, holding the mortgage fixed, individuals can now extract more equity from the house to buy working capital if they are to switch from fixed income to variable income. The null hypothesis that current home equity has no effect on future business ownership is rejected with $p<0.01$. The point estimate

of the home equity coefficient implies that for an individual with the sample mean demographic and income characteristics, an increase in the value of the property that results in a doubling of home equity increases the probability that the household will transition into entrepreneurship in the future by $0.3 \%$.

Column (2) of Table 3 replicates Column (1) with entrepreneurship defined as the probability of a non-business owner becoming an entrepreneur in the very next period. This allows us to include all observations of households which are interviewed more than once, and not just the first observation. The results remain qualitatively unchanged: the strong positive association between 
home equity and transition to entrepreneurship survives this alternative definition of the switching horizon. Again, the null hypothesis that current home equity has no effect on future business ownership is rejected with $p<0.01$. The point estimate of the home equity coefficient implies that for an individual with the sample mean demographic and income characteristics, an increase in the value of the property that results in a doubling of home equity increases the probability that the household will transition into entrepreneurship in the future by $0.2 \%$.

In Columns (3) and (4), we repeat the regressions in (1) and (2), but this time we also add the natural logarithm of the value of the house on the right-hand side of the regression. In this way, we control for the impact of home values on entrepreneurship through the "luxury good" channel. Namely, if home value appreciation makes the homeowner feel wealthier and by extension, increases her willingness to purchase the luxury attributes that come with self-employment (such as flexible working time or the ability to work from home), our estimate of the the collateral channel may be upward biased. Our results point to such wealth effect of property value appreciation, but the effect is not significant. Importantly, the estimate of the collateral channel survives this alternative test.

\subsection{Alternative definitions of entrepreneurship}

In Table 4, we replicate the first two columns of Table 3 after employing alternative definitions of business ownership. In Column (1), we define transition into business ownership as a dummy variable equal to one if the household declares zero business equity in the current period but positive business equity in the future. This definition accounts for the fact that individuals may become business owners not just by starting a business themselves, but also by investing in other agents' businesses. In Column (2), we use the same definition but look at whether households acquire business equity in the very next period. In both cases, the null hypothesis that current home equity has no effect on future business equity ownership is rejected with $p<0.01$. In terms 
of numerical effect, for example the point estimate of the home equity coefficient in Column (1) implies that an increase in the value of the property that results in a doubling of home equity, holding everything else at their sample mean values increases the probability that the household that presently owns no business equity will own business equity in the future by $0.5 \%$.

\section{Insert Table 4 here}

In the next two columns of Table 4, we employ the definition used in Hurst and Lusardi (2004), namely, we define business owners as households which are either running and operating their own business or own business equity. We find that the positive association between home equity and the probability of transition into business ownership continues to be statistically strong (at the $1 \%$ level) for this broader definition of entrepreneurship. Importantly, all regressions in Table 4 include our exhaustive set of variables which proxy for demographic characteristics, liquid wealth, disposable income, the local business cycle, and homestead exemptions. This implies that the positive correlation between home equity and business ownership is not due to the high correlation between home equity and liquid wealth, disposable income, or changes in the return to entrepreneurship.

\subsection{Instrumental variables results}

We now proceed to address various issues related to the possibility that we have detected a purely spurious correlation between home equity and the probability of transition into entrepreneurship. In particular, as pointed out by Chetty and Szeidl (2012), households may vary in the degree of their risk aversion. If housing is considered a risky investment, more risk averse individuals may prefer to buy smaller houses, resulting in lower home equity. If more risk averse individuals are also less likely to transition into entrepreneurship, then the positive association between home equity and business ownership will be entirely spurious.

To account for such a possibility, we employ the identification strategy outlined in Section 4. In Table 5, we repeat the empirical exercises reported in Tables 3 and 4 in the case of future 
business ownership, but this time we instrument home equity with the average housing prices in the household's state in the current year and the average housing prices in the household's state in the year in which it bought the house, both interacted with the state-level topological elasticity of housing supply from Saiz (2010). Both instruments are expected to capture an exogenous variation in home equity: higher housing prices in the past imply higher mortgage in the past and so lower equity today, while higher housing prices today imply higher equity for houses with identical purchase prices because of house price appreciation. ${ }^{1}$

\section{Insert Table 5 here}

Even with this identification strategy at hand, the null hypothesis that current home equity has no effect on future business ownership is rejected in two of the three cases, with $p<0.01$ in Column (1) and $p<0.05$ in Column (3). The point estimate of the home equity coefficient implies that an increase in the value of the property that results in a doubling of home equity increases the probability that the household will transition into entrepreneurship in the future by about $1.5 \%$ (Column (1)), and by about $1 \%$ the probability of acquiring business equity in the future (Column (2)). For the definition of entrepreneurship used by Hurst and Lusardi (2004), a doubling of home equity, holding everything else at the sample mean values, raises the probability of transition into entrepreneurship by $2.3 \%$. The increase in the magnitude of the coefficients relative to the OLS case implies that the OLS estimates are downward biased, potentially because a larger house may be considered a safe rather than a risky investment. Hence, risk-averse individuals - also the ones less likely to become entrepreneurs - may be buying larger houses, introducing a negative correlation between home equity and business ownership.

\footnotetext{
${ }^{1}$ The first-stage regressions (available upon request) imply that just like in Chetty and Szeidl (2012), the relevance condition for the two instruments is satisfied.
} 


\subsection{The effect of housing booms}

The next prediction of our model that we want to test is captured by Figure 2. Agents switch from fixed income to entrepreneurship earlier during house price boom. The intuition behind this result is that holding current home equity constant, would-be entrepreneurs will be on the margin more likely to switch to business ownership if they expect to be able to extract more equity from their house in the future to cover capital expenditures. This effect will be larger for agents with a larger mortgage at present as they expect a higher increase in home equity in the future. In this sense, we distinguish the direct effect of housing booms, which may be stimulating entrepreneurship by signaling conditions associated with a favorable business environment, from its indirect effect through the collateral channel.

In order to test this prediction, we need to generate a variable capturing regional U.S. house price booms over the sample period. To capture periods of persistent high house price appreciation at U.S. state level, we introduce the variable HHMI (Hot Housing Market Indicator). This is a binary variable that is calculated using the estimated smooth probabilities from the Markov-switching model on real housing returns using the quarterly FHFA house price indexes for each state and the U.S. aggregate. To go from these estimated probabilities to a binary variable, we assume that the binary variable $\mathrm{HHMI}_{j t}$ for the U.S. state $j$ (i.e. $j=$ California) at time $t$ is equal to one when the following two conditions hold: (i) the smooth probability of being in the regime associated with the highest expected real housing return of state $j$ is higher than its historical average plus half of its historical standard deviation four consecutive quarters; and (ii) the real housing return of state $j$ is higher than the expected real housing return in the high-growth regime of the U.S. aggregate in the same four quarters of point (i).

HHMI is based on these two conditions because they embed two specific pieces of information. The first condition captures the likelihood that there has been a regime switch in state $j$ based on a turning point probability. We define the turning point probability when the estimated smooth 
probability reaches a $90 \%$ statistical level. The logic underlying the first condition is to detect whether a housing market peak relative to its historical average in state $j$ has been reached and it has lasted at least four quarters in a row. Hence, condition (i) allows us to classify states' house prices according to the degree of cyclicality in their real housing returns. ${ }^{2}$ The second condition verifies whether the real housing return in state $j$ is substantially high when compared to the overall U.S. housing market.

Figure 3 depicts the inferred smoothed probability of being in the regime of high mean growth rates for California, Florida, Massachusetts and Nevada. This figure shows the pronounced cyclicality in the quarterly house price growth for California and Massachusetts. High-growth periods in these two states tend to occur relatively frequently and tend to be long in duration. Instead, Florida and Nevada have less pronounced cycles.

\section{Insert Figure 3 here}

HHMI is introduced in Equation (12), both on its own and in interaction with home equity, in Table 6. Column (1) of Table 6 replicates Column (1) of Table 3 with the addition of these two new explanatory variables. We again include interactions of state and year fixed effects to control for a wide range of state-level unobservables that vary over time. These subsume the direct effect of hot housing markets on entrepreneurship. The interaction of "Housing boom" with home equity turns out to have the expected sign: households with lower home equity are more likely to transition into entrepreneurship in hot housing markets as they expect to extract more home equity in the future. On its own, home equity is still positively correlated with the probability of future transition into entrepreneurship. Both effects are significant at the $1 \%$ statistical level.

\footnotetext{
${ }^{2}$ The condition that the smooth probability of being in the regime associated with the highest expected real housing return reaches the turning point probability is satisfied in some periods by states such as California and Florida in which housing markets experienced a particularly high appreciation in the same periods. Hence, these periods are generally characterized by high and pronounced appreciation in house prices. Differently, condition (i) is not satisfied by states such as Alabama and Montana whose housing markets have experienced prolonged and continuous high-growth phases that are mainly characterized by modest growth in house prices.
} 


\section{Insert Table 6 here}

In Column (2), we use our instrumental variable procedure. We add two more instruments, namely, the interaction of the two instruments introduced in Table 5 with the "Housing boom" indicator. The result related to the collateral channel is significant at the $1 \%$, implying that for low levels of home equity, a hot housing market may stimulate entrepreneurship by allowing households to extract more equity in the future to invest in their business. The magnitude of the coefficient on the interaction term increases five-fold, implying that OLS may be downward-biased, potentially because risk aversion is higher when housing markets are booming.

\subsection{Business equity, home equity, and the transition to entrepreneurship}

So far we have only tested the predictions of our model related to the effect of home equity on the decision to switch from a fixed wage to being an entrepreneur. In this section, we test the implications of the model related to ownership of business equity. In particular, the model predicts that once the agent transitions into entrepreneurship, she draws down all her home equity in order to invest in her new business. This implies a negative relationship between home equity and business equity. In addition, as Figure 2 indicates, hot housing markets should also result in higher business ownership by allowing the agents to leverage more from the value of their property. This set of predictions implies that we should account simultaneously for property values and for home equity in our regressions of business equity. Holding property values constant, higher home equity (lower mortgage) should result in lower business equity; and holding home equity constant, higher property values (higher mortgage) should result in higher business equity. Including property values on the right-hand side in the regression also allows us to control for the "luxury good" component of entrepreneurship.

Table 7 reports tests this prediction of the mode. We start, in Column (1), with a test of whether business owners do indeed invest more in business equity than non-business owners. This test is 
performed on the full sample of households. We find that they do, and this effect is significant at the $1 \%$ level. In the next two columns, we report estimates from OLS and IV regressions of business equity on home equity, for business owners only, controlling for the full set of the household's demographic and financial characteristics. Column (2) reports our OLS estimates for individuals with strictly positive business equity at the beginning of each interview wave. This reduces our sample to 5,704 observations. In this specification, we find a strong support for the predictions of the model. In particular, there is a strong negative correlation between home equity and business equity for business owners. This implies that, as predicted by the model, once individuals transition into entrepreneurship, they lever up as much as possible by drawing down the equity from their homes and investing it in their business.

\section{Insert Table 7 here}

To account for potential omitted variable bias that may contaminate the effect of home equity on business equity, in Column (3) of Table 7 we employ our identification strategy. In particular, we instrument the main explanatory variable with our two main instruments (the average house prices in the household's state in the current year and the average house prices in the household's state in the year in which it bought the house, interacted with the state-level topological measure of the elasticity of housing supply). Once again, the effect of home equity has the predicted sign, and it is significant at the $5 \%$ level.

\subsection{Home equity and non-mortgage debt}

An indirect prediction of our model is that if a house is efficient collateral, then business owners with higher home equity are likely to finance their business differently from business owners with no access to home equity. In particular, one would expect that business owners with access to home equity would accumulate less certain types of non-mortgage debt, such as consumer debt. Such evidence would provide a fuller picture of the collateral channel associated with higher housing 
prices. In Table 8, we test this prediction explicitly. We first calculate the household's total nonmortgage debt by subtracting the value of the mortgage from the value of total debt that the household reports. The resulting variable should include liabilities such as credit card borrowing and consumer loans. Then we repeat the test in Equation (11), with the natural logarithm of total non-mortgage debt as the independent variable. We do so for the sub-sample of business owners only, defined as households with positive business equity. The estimates strongly suggest that indeed business owners with access to higher home equity are less leveraged in terms of nonmortgage debt. The effect is statistically significant at the $1 \%$ level both in the OLS (Column (1)) and in the IV (Column (2)) specification.

\section{Insert Table 8 here}

Next, we take a more restricted view and calculate the household's consumer debt by subtracting the sum of mortgage debt and business debt from total household debt. This leaves us with a cleaner proxy for unsecured debt. Once again, we find that business owners with access to higher home equity accumulate less unsecured debt, although the effect is significant only in the OLS case (Column (3)). Our results broadly confirm the conjecture that the financing of the business is different when the business owner can readily use her house as collateral.

\section{Conclusion}

In this paper, we estimate the causal effect of home equity and leverage on entrepreneurship. We define entrepreneurship as the probability of owning and operating a business, as the probability of owning strictly positive business equity, or as either of the two. For all definitions, we find a strong positive effect of home equity on the probability that a non-business owning household will switch to entrepreneurship in the future. Numerically, a doubling of home equity increases the probability that a non-business owning household will become entrepreneurs in the future by up to $2.4 \%$. This 
effect is robust to controlling for a wide range of demographic and income characteristics, for the local business cycle, and for the bankruptcy code. It also exists independently of a "luxury good" component of housing whereby individuals whose house is appreciating in value can be more likely to purchase the non-pecuniary benefits associated with running a business.

We also find that these effects are stronger during housing booms when agents can switch to entrepreneurship at lower levels of home equity because they expect to be able to extract more equity in the future. Finally, we find a strong negative correlation between home equity and business equity for business owners, implying that once agents switch from a fixed-income job to entrepreneurship, they draw down their home equity to finance their business investment. Business owners with higher home equity also use less non-housing and consumer debt, implying that a house is indeed efficient collateral.

In order to make sure that our results are not driven by an unobservable individual trait, such as risk aversion, we employ an Instrumental Variable procedure whereby we use the topological elasticity of housing supply in the agent's state to extract the exogenous component of changes in home equity. We also perform our tests for a number of definitions of entrepreneurship, such as actual ownership of a business, ownership of business equity, or any of the two. Our results remain stubbornly robust to these alternative specifications.

Our reduced form estimates imply potentially important linkages between housing and real economic activity. For example, our results suggest that the housing boom before the Great Recession may have resulted in higher rates of new business creation, while increasing levels of mortgage debt since 2006 may have depressed self-employment, denting the positive effect on new business creation of higher unemployment. As such, our results may have important implications for various policy initiatives aimed at reducing the burden of household leverage during the recession. In future work, it would also be interesting to incorporate an analysis of the implications for entrepreneurship of reducing transaction costs in the housing market and of various exemptions related to housing in 
the case of personal bankruptcy. 


\section{References}

Berkowitz, J., and M. White, 2004. Bankruptcy and small firms' access to credit. RAND Journal of Economics 35, 69-84.

Blanchflower, D., and A. Oswald, 1998. What makes an entrepreneur? Journal of Labor Economics 16, 26-60.

Buera, F., 2009. A dynamic model of entrepreneurship with borrowing constraints: theory and evidence. Annals of Finance 5, 443-464.

Cagetti, M., and M. De Nardi, 2006. Entrepreneurship, frictions, and wealth. Journal of Political Economy 114, 835-870.

Chaney, T., Sraer, D., and D. Thesmar, 2012. The collateral channel: How real estate shocks affect corporate investment. American Economic Review, forthcoming.

Chetty, R., and A. Szeidl, 2007. Consumption commitments and risk preferences. Quarterly Journal of Economics 122, 831-877.

Chetty, R., and A. Szeidl, 2012. The effect of housing on portfolio choice. NBER Working Papers 15998.

Corradin, S., Fillat, J., and C. Vergara-Alert, 2012. Optimal portfolio choice with predictability in house prices and transaction costs. ECB Working Paper.

Eberly, J., 1994. Adjustment of consumers' durables stocks: Evidence from automobile purchases. Journal of Political Economy 102, 403-436.

Evans, D., and B. Jovanovic, 1989. An estimated model of entrepreneurial choice under liquidity constraints. Journal of Political Economy 97, 808-827.

Evans, D., and L. Leighton, 1989. Some empirical aspects of entrepreneurship. American Economic Review 79, 519-535. 
Fairlie, R., 1999. The absence of the African-American owned business: An analysis of the dynamics of self-employment. Journal of Labor Economics 17, 80-108.

Fairlie, R., 2010. The great recession and entrepreneurship. University of California at Santa Cruz working paper.

Grossman, S., and G. Laroque, 1990. Asset pricing and optimal portfolio choice in the presence of illiquid durable consumption goods. Econometrica 58, 25-51.

Hamilton, B., 2000. Does entrepreneurship pay? An empirical analysis of the returns to selfemployment. Journal of Political Economy 108, 604-631.

Holtz-Eakin, D., Joulfaian, D., and H. Rosen, 1994. Sticking it out: Entrepreneurial survival and liquidity constraints. Journal of Political Economy 102, 53-75.

Hurst, E., and A. Lusardi, 2004. Liquidity constraints, household wealth, and entrepreneurship. Journal of Political Economy 112, 319-347.

Hurst, E., and F. Stafford, 2004. Home is where the equity Is: liquidity constraints, refinancing and consumption. Journal of Money Credit and Banking 36(6), 985-1014.

Kiyotaki, N., and J. Moore, 1997. Credit cycles. Journal of Political Economy 105, 211-248.

Mian, A., and A. Sufi 2010. House prices, home equity-based borrowing, and the U.S. household leverage crisis. American Economic Review 5 (101): 2132-2156.

Paulson, A., and . Townsend, 2004. Entrepreneurship and financial constraints in Thailand. Journal of Corporate Finance 10, 229-326.

Midrigan, V., and T. Philippon, 2011. Household leverage and the recession. NBER Working Papers 16965.

Quadrini, V., 1999. The importance of entrepreneurship for wealth concentration and mobility. Review of Income and Wealth 45, 1-19. 
Quadrini, V., 2000. Entrepreneurship, saving and social mobility. Review of Economic Dynamics $3,1-40$.

Saiz, A., 2010. The geographic determinants of housing supply. Quarterly Journal of Economics, vol. 125(3), August 2010, pp.1253-1296. 


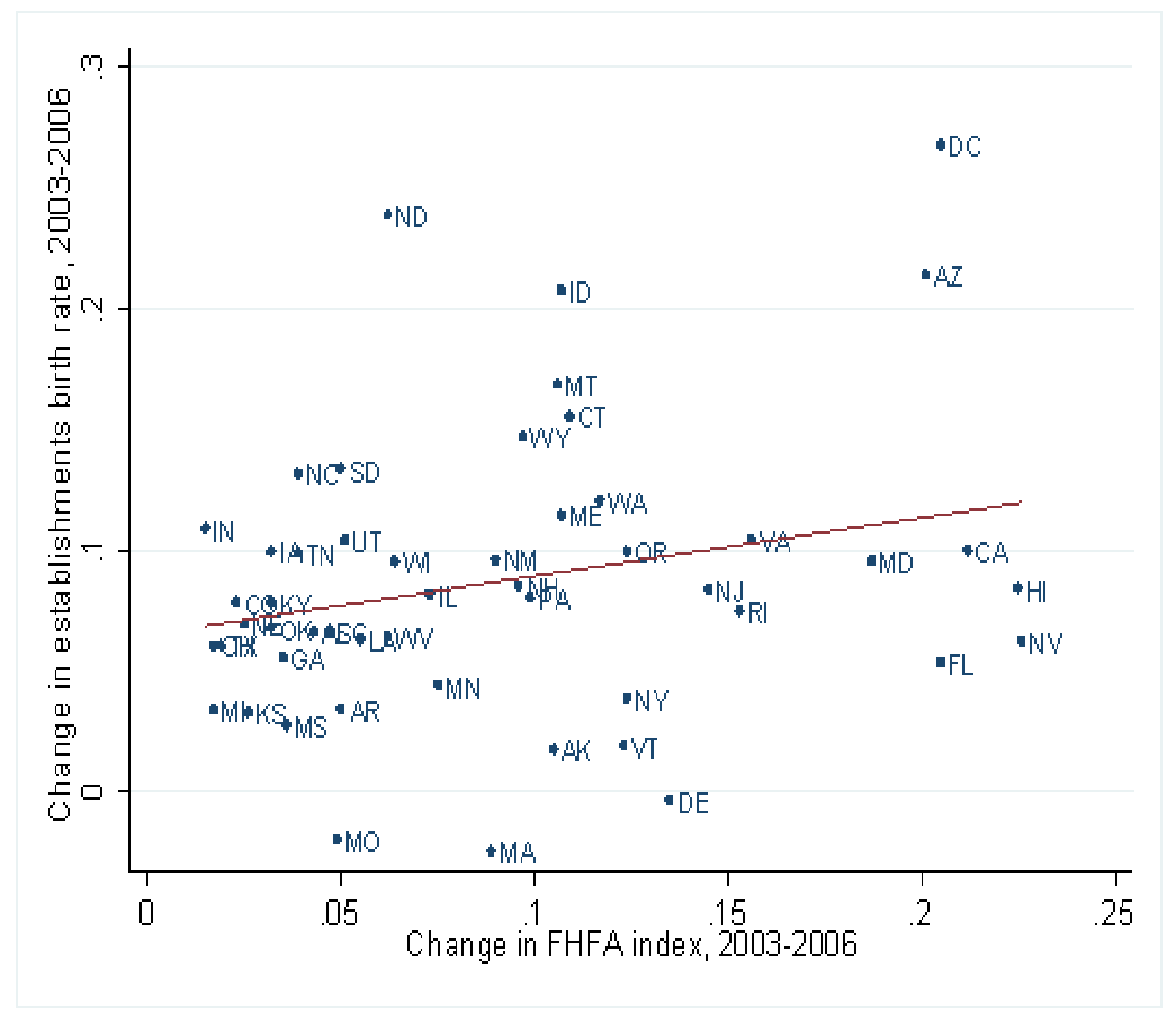

Figure 1: The figure plots the change in establishments births between 2003 and 2006 (the peak of the housing boom) against the change in the state-level Federal Housing Finance Agency house price indexes over the same period, inflation adjusted, for the 50 U.S. states plus the District of Columbia. 

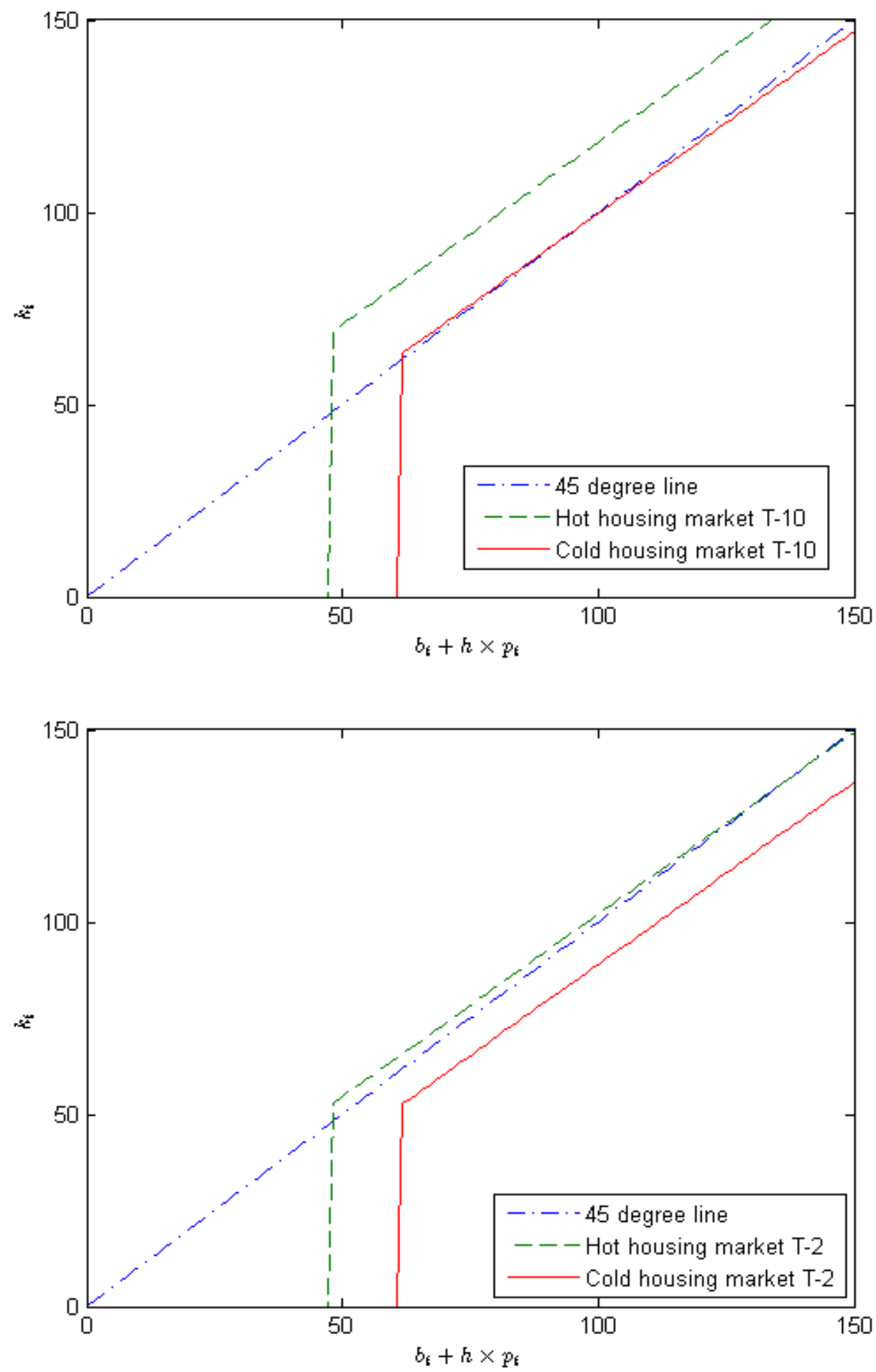

Figure 2: The figure plots the investment in the entrepreneurial activity $k$ with respect to the liquid and housing wealth $b_{t}+h \times p_{t}$, in a period of low (solid red line) and high (dashed green line) house price appreciation at time $T-10$ (upper panel) and $T-2$ years (lower panel). 


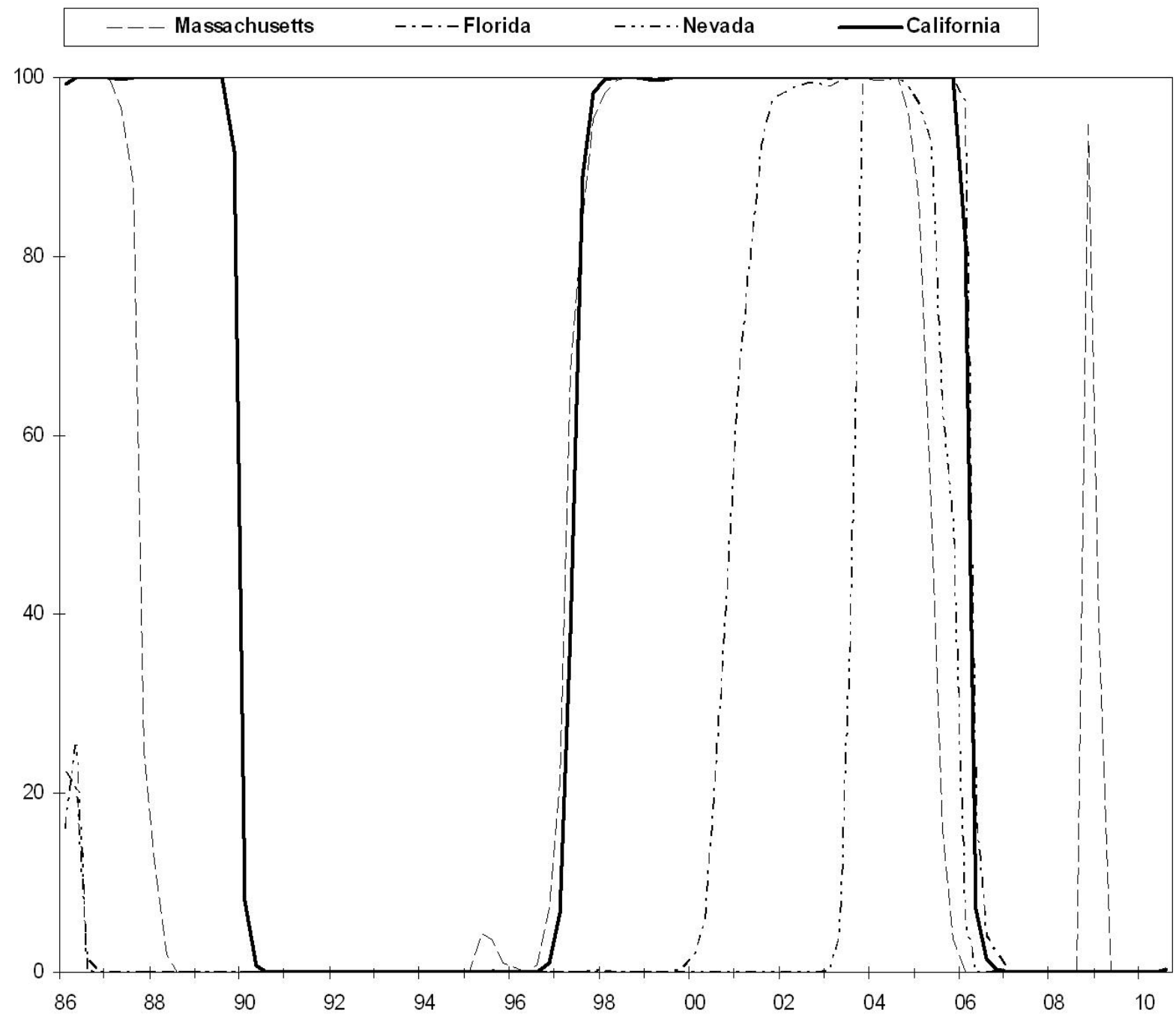

Figure 3: Probability of being in a high regime of house price returns - U.S. states. Probabilities of being in a high regime for California, Florida, Nevada and Massachusetts. 
Table 1: Parameter used for benchmark calibration.

\begin{tabular}{lcc}
\hline Variable & Symbol & Value \\
\hline Horizon & $T$ & 20 (years) \\
Curvature of the utility function & $\gamma$ & 2 \\
Housing consumption relative to numerarire & $1-\beta$ & 0.4 \\
Flow of housing services & $g$ & 0.075 \\
Time preference & $\rho$ & 0.03 \\
Risk free rate & $r_{D}$ & 0.03 \\
Intermediation cost & $\epsilon$ & 0.01 \\
Loan-to-value ratio & $\phi$ & 0.9 \\
Housing stock & $H$ & 100 (square feet) \\
House price drift - high growth regime & $\mu_{h}$ & 0.0925 \\
House price drift - low growth regime & $\mu_{l}$ & 0.004 \\
House price - Prob. switching from high to low & $\lambda_{h l}$ & 0.241 \\
House price - Prob. switching from low to high & $\lambda_{l h}$ & 0.034 \\
House price standard deviation & $\sigma$ & 0.10 \\
Capital depreciation & $\delta$ & 0.09 \\
Capital share & $\alpha$ & 0.8 \\
Enterpreneurial ability - high regime & $\bar{\nu}$ & 0.9 \\
Enterpreneurial ability - low regime & $\underline{\nu}$ & 0.1 \\
Enterpreneurial ability - Prob. switching from high to low & $\theta_{h l}$ & 0.30 \\
Enterpreneurial ability - Prob. switching from low to high & $\theta_{l h}$ & 0.40 \\
Fixed wage & $l$ & 15 \\
\hline
\end{tabular}


Table 2. Descriptive Statistics of New Business Owners and Non-Business Owners: Pooled Sample 1997-2006.

\begin{tabular}{lccc}
\hline \multicolumn{1}{c}{ Variable } & $\begin{array}{c}\text { Subsequent } \\
\text { non-business } \\
\text { owner }\end{array}$ & $\begin{array}{c}\text { Subsequent } \\
\text { business } \\
\text { owner }\end{array}$ & $\begin{array}{c}p \text {-value } \\
\text { of difference }\end{array}$ \\
\hline Age of head & 43.38 & 43.4 & .51 \\
Education dummy (head) & & & \\
$\quad$ High school & 0.229 & 0.184 & $<.01$ \\
Some college & 0.333 & 0.303 & .07 \\
College or more & 0.336 & 0.444 & $<.01$ \\
Dummy: African American head & 0.086 & 0.029 & $<.01$ \\
Dummy: Female head & 0.457 & 0.394 & $<.01$ \\
Dummy: Household head is married & 0.700 & 0.789 & $<.01$ \\
Family labor income & $\$ 56,550$ & $\$ 62,228$ & .03 \\
Dummy: Household head is unemployed & 0.026 & 0.016 & .08 \\
Household net liquid worth & $\$ 130,876$ & $\$ 201,476$ & .08 \\
Home equity & $\$ 93,000$ & $\$ 120,000$ & $<.01$ \\
Household mortgage & $\$ 84,907$ & $\$ 96,741.6$ & $<.01$ \\
Home property value & $\$ 177,553$ & $\$ 216,317$ & $<.01$ \\
\hline Notes: The sample inclu
\end{tabular}

Notes: The sample includes all households in SIPP for the 1996-2000, 2001-2003, and 2004-2006 waves, between the age of 22 and 60 that did not own a business the first time they were interviewed. All statistics are means. The unweighted percentage of households that became subsequent business owners is 0.017 . 
Table 3. Future Business Ownership and Home Equity: OLS Results from the Pooled Sample 1997-2006.

\begin{tabular}{|c|c|c|c|c|}
\hline & $\begin{array}{c}\text { Business owner } \\
\text { in future } \\
(1)\end{array}$ & $\begin{array}{c}\text { Business owner } \\
\text { next period }\end{array}$ & $\begin{array}{c}\text { Business owner } \\
\text { in future } \\
(1) \\
\end{array}$ & $\begin{array}{c}\text { Business owner } \\
\text { next period }\end{array}$ \\
\hline Log (Home equity) & $\begin{array}{l}0.072 * * * \\
(0.021)\end{array}$ & $\begin{array}{l}0.063 * * * \\
(0.020)\end{array}$ & $\begin{array}{l}0.055^{* * *} \\
(0.018)\end{array}$ & $\begin{array}{l}0.032^{*} \\
(0.019)\end{array}$ \\
\hline Log (House value) & & & $\begin{array}{l}0.041 \\
(0.052)\end{array}$ & $\begin{array}{l}0.075 \\
(0.050)\end{array}$ \\
\hline Age & $\begin{array}{l}-0.002 \\
(0.002)\end{array}$ & $\begin{array}{l}-0.001 \\
(0.002)\end{array}$ & $\begin{array}{l}-0.001 \\
(0.002)\end{array}$ & $\begin{array}{l}-0.000 \\
(0.002)\end{array}$ \\
\hline High school & $\begin{array}{l}0.065 \\
(0.076)\end{array}$ & $\begin{array}{l}0.237 * * * \\
(0.083)\end{array}$ & $\begin{array}{l}0.063 \\
(0.076)\end{array}$ & $\begin{array}{l}0.239 * * * \\
(0.083)\end{array}$ \\
\hline Some college & $\begin{array}{l}0.043 \\
(0.072)\end{array}$ & $\begin{array}{l}0.240 * * * \\
(0.072)\end{array}$ & $\begin{array}{l}0.037 \\
(0.073)\end{array}$ & $\begin{array}{l}0.234 * * * \\
(0.072)\end{array}$ \\
\hline College or more & $\begin{array}{l}0.172 * * \\
(0.083)\end{array}$ & $\begin{array}{l}0.343 * * * \\
(0.079)\end{array}$ & $\begin{array}{l}0.160 * * \\
(0.085)\end{array}$ & $\begin{array}{l}0.328 * * * \\
(0.081)\end{array}$ \\
\hline Wealth & $\begin{array}{l}0.017 * * * \\
(0.006)\end{array}$ & $\begin{array}{l}0.017 * * * \\
(0.005)\end{array}$ & $\begin{array}{l}0.016^{* *} \\
(0.006)\end{array}$ & $\begin{array}{l}0.016 * * * \\
(0.005)\end{array}$ \\
\hline Wealth $\wedge 2$ & $\begin{array}{l}-0.000 \\
(0.000)\end{array}$ & $\begin{array}{l}-0.001 \\
(0.001)\end{array}$ & $\begin{array}{l}-0.000 \\
(0.000)\end{array}$ & $\begin{array}{l}-0.001 \\
(0.001)\end{array}$ \\
\hline Wealth $\wedge 3$ & $\begin{array}{l}0.000 \\
(0.000)\end{array}$ & $\begin{array}{l}0.000 \\
(0.000)\end{array}$ & $\begin{array}{l}0.000 \\
(0.000)\end{array}$ & $\begin{array}{l}0.000 \\
(0.000)\end{array}$ \\
\hline Earned income & $\begin{array}{l}-0.356 \\
(0.358)\end{array}$ & $\begin{array}{l}-0.234 \\
(0.288)\end{array}$ & $\begin{array}{l}-0.412 \\
(0.382)\end{array}$ & $\begin{array}{l}-0.341 \\
(0.324)\end{array}$ \\
\hline Female & $\begin{array}{l}-0.049 \\
(0.035)\end{array}$ & $\begin{array}{l}-0.040 \\
(0.035)\end{array}$ & $\begin{array}{l}-0.049 \\
(0.036)\end{array}$ & $\begin{array}{l}-0.040 \\
(0.035)\end{array}$ \\
\hline Black & $\begin{array}{l}-0.281 * * * \\
(0.080)\end{array}$ & $\begin{array}{l}-0.245 * * * \\
(0.077)\end{array}$ & $\begin{array}{l}-0.275^{* * * *} \\
(0.082)\end{array}$ & $\begin{array}{l}-0.235^{* * * *} \\
(0.077)\end{array}$ \\
\hline Married & $\begin{array}{l}0.110 * * * \\
(0.035)\end{array}$ & $\begin{array}{l}0.120 * * * \\
(0.037)\end{array}$ & $\begin{array}{l}0.106^{* * * *} \\
(0.035)\end{array}$ & $\begin{array}{l}0.112 * * * \\
(0.038)\end{array}$ \\
\hline Unemployed & $\begin{array}{l}-0.184^{* *} \\
(0.093)\end{array}$ & $\begin{array}{l}-0.079 \\
(0.091)\end{array}$ & $\begin{array}{l}-0.183^{* *} \\
(0.093)\end{array}$ & $\begin{array}{l}-0.078 \\
(0.091)\end{array}$ \\
\hline State unemployment & $\begin{array}{l}0.061 * * \\
(0.031)\end{array}$ & $\begin{array}{l}0.043 \\
(0.030)\end{array}$ & $\begin{array}{l}0.060 * * \\
(0.031)\end{array}$ & $\begin{array}{l}0.042 \\
(0.030)\end{array}$ \\
\hline GSP growth & $\begin{array}{l}-0.017 \\
(0.014)\end{array}$ & $\begin{array}{l}-0.011 \\
(0.014)\end{array}$ & $\begin{array}{l}-0.017 \\
(0.014)\end{array}$ & $\begin{array}{l}-0.011 \\
(0.014)\end{array}$ \\
\hline Homestead exemption & $\begin{array}{l}0.060 * * * \\
(0.021)\end{array}$ & $\begin{array}{l}0.053 * * \\
(0.025)\end{array}$ & $\begin{array}{l}0.059 * * * \\
(0.021)\end{array}$ & $\begin{array}{l}0.052 * * \\
(0.025)\end{array}$ \\
\hline Fixed effects & & & $\begin{array}{l}\text { State } \\
\text { Year }\end{array}$ & \\
\hline Observations & 39,999 & 53,741 & 39,999 & 53,741 \\
\hline R-squared & 0.03 & 0.03 & 0.03 & 0.03 \\
\hline
\end{tabular}


Table 4. Future Business Equity and Home Equity: OLS Results from the Pooled Sample 1997-2006.

\begin{tabular}{lcccc}
\hline & $\begin{array}{c}\text { Business equity } \\
\text { in future }\end{array}$ & $\begin{array}{c}\text { Business owner or } \\
\text { business equity } \\
\text { in future }\end{array}$ & $\begin{array}{c}\text { Business equity } \\
\text { next period }\end{array}$ & $\begin{array}{c}\text { Business owner or } \\
\text { business equity } \\
\text { next period }\end{array}$ \\
\cline { 2 - 5 } & $(1)$ & $(2)$ & $(3)$ & $(4)$ \\
\hline Log (Home equity) & $0.052^{* * *}$ & $0.067^{* * *}$ & $0.050^{* * *}$ & $0.057^{* * *}$ \\
Income/demographic & $(0.013)$ & $(0.014)$ & $(0.013)$ & $(0.012)$ \\
controls included? & \multicolumn{5}{c}{ Yes } \\
Fixed effects & \multicolumn{5}{c}{$\begin{array}{c}\text { State } \\
\text { Observations }\end{array}$} & \multicolumn{5}{c}{ Year } \\
R-squared & 33,147 & 32,949 & 75,854 & 75,616 \\
\hline
\end{tabular}

Note: The table reports probit estimates of owning business equity in the future (column (1)) or in the next period (column (3)), and of either being a business owner or owning business equity, in the future (column (2)) or in the next period (column (4)). The sample is composed of all households in SIPP for the 1996-2000, 2001-2003, and 2004-2006 waves, between the age of 22 and 60 that did not own a business the first time they were interviewed. Standard errors clustered by state are reported in parentheses. 
Table 5. Future Business Ownership and Home equity: IV Results from the Pooled Sample 1997-2006.

\begin{tabular}{lccc}
\hline & $\begin{array}{c}\text { Business owner } \\
\text { in future }\end{array}$ & $\begin{array}{c}\text { Business equity } \\
\text { in future }\end{array}$ & $\begin{array}{c}\text { Business owner or } \\
\text { business equity } \\
\text { in future }\end{array}$ \\
\cline { 2 - 4 } & $(1)$ & $(2)$ & $(3)$ \\
\hline Log (Home equity) & $0.400^{* * *}$ & 0.043 & $0.098^{*}$ \\
Income/demographic controls included? & $(0.124)$ & $(0.068)$ & $(0.067)$ \\
Fixed effects & & Yes & State \\
Observations & & Year & 37,138 \\
R-squared & 37,058 & 37,080 & 0.06 \\
\hline
\end{tabular}

Note: The table reports probit estimates of the transition into business ownership in the future (column (1)), of owning business equity in the future (column (2)), and of either being a business owner or owning business equity in the future (column (3)). The sample is composed of all households in SIPP for the 1996-2000, 20012003, and 2004-2006 waves, between the age of 22 and 60 that did not own a business the first time they were interviewed. 'Log (Home equity)' is instrumented using the average price in the state in the present year and in the year when the house was bought, both interacted with the state-level topological elasticity of housing supply from Saiz (2010). Standard errors clustered by state are reported in parentheses. 
Table 6. Future Business Ownership, Home Equity, and Housing Booms: OLS and IV Results from the Pooled Sample 1997-2006.

\begin{tabular}{|c|c|c|}
\hline & \multicolumn{2}{|c|}{ Business owner in future } \\
\hline & OLS & IV \\
\hline & (1) & $(2)$ \\
\hline \multirow[t]{2}{*}{ Log (Home equity) } & $0.277 * * *$ & $0.226 * * *$ \\
\hline & $(0.069)$ & $(0.036)$ \\
\hline \multirow[t]{2}{*}{ Log (Home equity) $\times$ Housing boom } & $-0.049 * * *$ & $-0.061 * * *$ \\
\hline & $(0.018)$ & $(0.015)$ \\
\hline Income/demographic controls included? & \multicolumn{2}{|c|}{ Yes } \\
\hline Fixed effects & \multicolumn{2}{|c|}{ State $\times$ Year } \\
\hline Observations & 40,024 & 37,080 \\
\hline R-squared & 0.01 & 0.01 \\
\hline
\end{tabular}

Note: The table reports OLS and IV estimates of the transition into business ownership in the future. The sample is composed of all households in SIPP for the 1996-2000, 2001-2003, and 2004-2006 waves, between the age of 22 and 60 that did not own a business the first time they were interviewed. 'Housing boom' is a binary variable indicating a state-wide hot housing market (See Section 6.3 for details). In column (2), 'Log (Home equity)' and 'Log (Home equity) $\times$ Housing boom' are instrumented using the average price in the state in the present year and in the year when the house was bought, both interacted with the state-level topological elasticity of housing supply from Saiz (2010), as well as the interactions of the two composite variables with 'Housing boom'. Standard errors clustered by state are reported in parentheses. 
Table 7. Home Equity and Business Equity for Business Owners: OLS and IV Results from the Pooled Sample 1997-2006.

\begin{tabular}{|c|c|c|c|}
\hline & \multicolumn{3}{|c|}{ Log (Business equity) } \\
\hline & OLS & OLS & IV \\
\hline & (1) & $(2)$ & (3) \\
\hline Business owner & $\begin{array}{l}0.933 * * * \\
(0.086)\end{array}$ & & \\
\hline Log (Home equity) & & $\begin{array}{l}-0.054 * \\
(0.028)\end{array}$ & $\begin{array}{l}-1.329 * * \\
(0.548)\end{array}$ \\
\hline Income/demographic controls included? & & Yes & \\
\hline Fixed effects & & $\begin{array}{l}\text { State } \\
\text { Year }\end{array}$ & \\
\hline Observations & 123,048 & 5,704 & 5,935 \\
\hline R-squared & 0.07 & 0.34 & 0.09 \\
\hline
\end{tabular}

Note: The table reports OLS and IV estimates of business equity ownership. The sample is composed of all households in SIPP for the 1996-2000, 2001-2003, and 2004-2006 waves, between the age of 22 and 60 that own business equity the first time they were interviewed. In column (3), 'Log (Home equity)' is instrumented using the average price in the state in the present year and in the year when the house was bought, both interacted with the state-level topological elasticity of housing supply from Saiz (2010). Standard errors clustered by state are reported in parentheses. 
Table 8. Home Equity and Other Types of Finance for Business Owners: OLS and IV Results from the Pooled Sample 1997-2006.

\begin{tabular}{|c|c|c|c|c|}
\hline & \multicolumn{2}{|c|}{ Total non-mortgage debt } & \multicolumn{2}{|c|}{ Consumer debt } \\
\hline & OLS & IV & OLS & IV \\
\hline & $(1)$ & (2) & (3) & (4) \\
\hline Log (Home equity) & $\begin{array}{l}-0.052 * * * \\
(0.014)\end{array}$ & $\begin{array}{l}-0.302 * * * \\
(0.123)\end{array}$ & $\begin{array}{l}-0.046^{* * *} \\
(0.015)\end{array}$ & $\begin{array}{l}-0.071 \\
(0.123)\end{array}$ \\
\hline Income/demographic controls included? & \multicolumn{4}{|c|}{ Yes } \\
\hline Fixed effects & \multicolumn{4}{|c|}{ State } \\
\hline Observations & 13,320 & 12,478 & 12,202 & 11,425 \\
\hline R-squared & 0.11 & 0.09 & 0.08 & 0.08 \\
\hline
\end{tabular}

Note: The table reports OLS and IV estimates of various types of non-business debt. 'Total nonbusiness debt' refers to total household debt after debt against the business and mortgage debt have been subtracted. 'Consumer debt' refers to total household debt after all secured debt has been subtracted. The sample is composed of all households in SIPP for the 1996-2000, 20012003, and 2004-2006 waves, between the age of 22 and 60 that own business equity the first time they were interviewed. In columns (2) and (4), 'Log (Home equity)' is instrumented using the average price in the state in the present year and in the year when the house was bought, both interacted with the state-level topological elasticity of housing supply from Saiz (2010). Standard errors clustered by state are reported in parentheses. 